\title{
Community water supply project in Ikuru Town, Andoni, Rivers State: performance and challenges
}

\author{
Ijeoma Immaculata Nwajuaku ${ }^{1,}{ }^{*}$, Njideka Ophelia Ezetoha ${ }^{2}$ and Nwanneka Genevieve Ezeokoye ${ }^{1}$ \\ ${ }^{1}$ Department of Civil Engineering, Faculty of Engineering, Nnamdi Azikiwe University, P.M.B 5025 Awka Anambra State, \\ Nigeria. \\ 2 Department of Chemical Engineering, Federal polytechnic Oko, P.M.B. 021, Aguata Anambra State, Nigeria.
}

World Journal of Advanced Engineering Technology and Sciences, 2022, 05(01), 032-038

Publication history: Received on 12 December 2021; revised on 14 January 2022; accepted on 16 January 2022

Article DOI: https://doi.org/10.30574/wjaets.2022.5.1.0024

\begin{abstract}
The paper aims at evaluating the performances and challenges of a community water supply project in Ikulu town. At the outset of 2021, as the decade of action to deliver the sustainable development goals (SDG) by 2030 gets underway, Ikuru Town is not on track to achieve Goals 6 (clean water and sanitation). Assessment of the Ikuru water supply project involved two ways: visitation to the treatment plant to observe the condition of the facility and use of the unstructured interview. Water samples were collected after treatment from the user point. Sampling was repeated three times on three different days. Physicochemical and microbial qualities of water samples were analyzed, using the standard for examination of water and wastewater by APHA. Results showed that total coliform bacteria were present in the water sample. Iron concentration was above the WHO limit. The concentration of manganese was above the recommended level and Iron bacteria were also present after treatment. In conclusion, the water is not potable and palatable due to its objectionable taste and orange brown colour. Therefore, there is needs for drastic treatment of Ikulu community water project at the point source, using shock chlorination as a recommended method to improve its performance level. Moreover, supportive intervention is required from governmental institutions to overcome the challenges of this water project for sustainability.
\end{abstract}

Keywords: Water Supply; Ikuru Town; Performance; Challenges; Water treatment

\section{Introduction}

Rivers State is one of the oil-producing states in the Niger Delta region, where oil and gas companies have installed networks of pipelines used in transporting crude oil and natural gas within the region. There are also numerous oil fields scattered both in the dryland and swamp area of the region. One such oil field is Otakikpo Marginal oil field in OML 11, operated by Green Energy International Limited in partnership with Lekoil, which has its operational base in Ikuru town. At the outset of 2021, as the decade of action to deliver the sustainable development goals (SDG) by 2030 gets underway, the Andoni local government area of River State is not on track to achieve Goals 6 which is clean water and sanitation.

Even though there has been a mean annual rainfall from about $4500 \mathrm{~mm}$ around the coastal margin of Niger Delta [1] and numerous rivers that drain this region, the provision of potable water is a challenge for years to this town. Gas emissions causing noxious particulate fallout have rendered rainwater acidic. Hence rain harvesting is not possible for domestic purposes [2]. The only alternative for water to this area becomes groundwater resources, which has to be the ultimate source of potable water for the rural population [3]. Andoni is a coastal area with mangrove swamps and has a high salinity level which has rendered their water brackish and non-potable [2]. According to [4], the groundwater

\footnotetext{
${ }^{*}$ Corresponding author: Ijeoma Immaculata Nwajuaku

Department of Civil Engineering, Faculty of Engineering, Nnamdi Azikiwe University, P.M.B 5025 Awka Anambra State, Nigeria.
} 
classification of Ikuru based on geoelectrical sounding indicated that the saltwater contaminated zone is in the range of 5-20m while the freshwater (meters below ground surface) is to be within 0-5meters. Incidentally, these same groundwater reservoirs are polluted constantly at a high rate by natural and human activities (oil/gas exploration and exploitation). The Niger Delta Environmental Survey reported that the Niger River carries iron deposits from the sediments of Itakpe Iron Ore. Then, through the processes of dispersion, advection, and inter-aquifer exchange, move the pollutants to the groundwater aquifer. Groundwater studies in some areas in the Rivers State have shown increased levels in total dissolved solids (TDS), up to $2900 \mathrm{mg} / \mathrm{l}$. A High concentration of hydrocarbon content, with oil and grease at $71 \mathrm{mg} / \mathrm{l}$ in 2006 compared to $1.8 \mathrm{mg} / \mathrm{l}$ recorded 17 years earlier reported by the author [5,6].

The most contaminants are detected weeks, months, or years after entering the subsurface. Again, Pollutants may travel a great distance and affect a large portion of an aquifer before pollution is recognized. For instance, the oil spill of the Funiwa blowout of 1980 had adverse effects on groundwater at Fishtown in Bayelsa State. An ecological investigation carried out 18 months later revealed extensive environmental degradation of the area. The most contaminants are detected weeks, months, or years after entering the subsurface [7].

In Ikuru town, a community in the Adoni local government area, potable water supply has been a challenge over the years. In 2014, the former president of Nigeria, Dr Goodluck Jonathan, in line with sustainable development goals (SDG), through the office of the senior special assistant to the president on SDG, constructed a solar-powered water project for the Ikuru community. It was a public water supply scheme built to serve the community of Ikuru town. The water project had a solar system installed by a company known as Tuscany global business services. It was a solar project because Ikuru town does not have access to the national power grid, which slows down the progress of the community. However, the solar-powered water project did not serve the community for long. It had only one filter that was serving as a treatment unit and an elevated tank. Later, people abandoned the public water project because the water quality was low due to the high concentration of iron. That was as a result of insufficient depth of the deep well. A new water project was initiated and later completed by Shell Company. It started operation in January, 2021. Hence, this study aims at evaluating its performances and challenges.

\section{Methods}

\subsection{Area of study}

Ikuru Town with latitude 4o27'48" N longitude 7o28'24"E is located in Andoni Local Government Area in Rivers State, Southern Nigeria. It is a small coastland close to the Bight of Bonny, founded by King Ikuru Efuya and consists of a bank of mangroves with an interior swamp fed by rainwater. It has an annual precipitation of about $4000 \mathrm{~mm} \pm 200$. Ikuru town has a beautiful waterfront with a beach which is a $3.2 \mathrm{~km}$ drive on Atlantic Road from Ikuru main town. The beach runs from Oyorokoto Fishing settlement down to Queenstown in Opobo on $28.2 \mathrm{~km}$ distance with variable width from $26 \mathrm{~m}$ to $30 \mathrm{~m}$. The waterfront can be accessed either by land through Sakpenwa-Bori Road or by water from Bonny, Opobo, Akwa-Ibom state and Port Harcourt. Ikuru town is a tourist site, due to the natural white sand beach. The main occupation of the people of Ikulu is fishing. The source of their groundwater is a coastal aquifer.

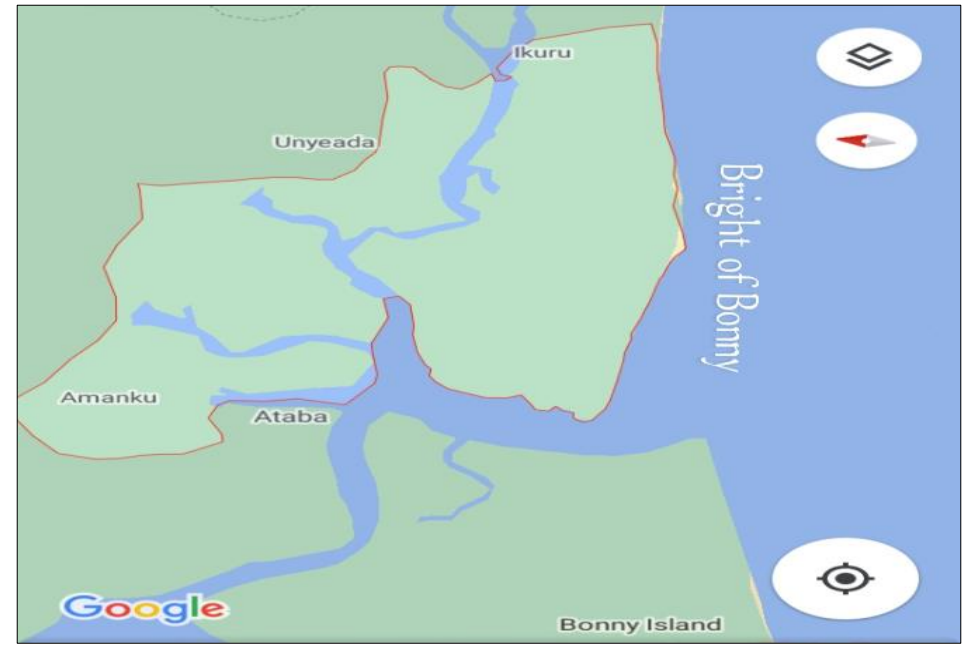

Figure 1 Goggle map of Andoni L.G.A showing Ikuru Town 


\subsection{Collection of data}

The assessment of the Ikuru water supply project using two methods involves; visitation to the treatment plant to observe the state of the facility. The second method is the use of the unstructured interview. This unstructured interview allows flexibility and adjustment of the questions according to the level of understanding of each participant. These participants are $90 \%$ Ikuru indigenes residing there, $4 \%$ plant operators and $6 \%$ youth corps members doing their primary assignments in that rural community. The researcher also used data collected from the plant operator on the operation and efficiency of the treatment plant. All information related to the Ikulu water supply project was analyzed and tabulated in Table 1.

\subsection{Water collection and Analysis}

Water samples were collected after treatment from the users point away from the treatment yard. Sampling was repeated three times for three different pumping days. The water was preserved in ice cubes and transported to Endpoint Laboratories and Equipment at No 138/16A, Road 2, Federal Housing Estate off Agip Road, Rumueme Port Harcourt, Rivers State. These samples were analyzed for physiochemical and microbial qualities using standard for the examination of water and waste water [8]. The parameters investigated includes total suspended solid (SS), total dissolve solid, taste, colour, turbidity, $\mathrm{pH}$, turbidity, iron, manganese, lead, hardness, free chlorine, nitrate, iron bacteria and coliform bacteria.

\section{Results}

\subsection{Current Status of the new water project}

The new water project has served the community for a few seven months since it started operation in January 2021. The source of this water project is from a deep well of a coastal aquifer (Figure 2a). The upper part of the casing is capped with iron pipe and extends at least $0.6 \mathrm{~m}$ above ground with a diameter of $0.3 \mathrm{~meter}$. The first treatment process is aeration. The type of aerator used in the Ikuru treatment plant is a cone aerator (Figure 2b). It oxidizes iron and manganese as a pretreatment measure. The aerator is of concrete- type with three stacked pans arranged such that water fills from the top pan and cascades down to each of them, down to the chemical system. This treatment unit uses two solution tanks and three different chemicals shown in Figure 1c. They are chlorine, calcium hypochlorite (HTHHigh Test Hypochlorite), and aluminum sulfate. Water from the aerator flows through a plumbing system to a chorine solution tank with a capacity of 15 gallon. It then moves to another 15-gallon capacity solution tank of alum and lime. The solution tank is for coagulation and water softening. The final treatment unit is a filtration system that consists of a pressure filter of $4 \mathrm{~m}$ in diameter, made of coated steel. At this unit, the operators believed that the treated water had attained a certain level of purification. There is no water analysis to test the quality of water before and after treatment. After the completion of the water treatment process, water flows to the overhead tank with the help of the high lift pumps. The capacity of the elevated tank is 50,000litre (Figure 2d). The pumping of water is two times a week. It takes 24 hours to fill the tank to serves the community for three days before the next pumping. A lister-generator is used to power the operation of the treatment system. The water flows out through water points placed at different locations within the community.

\subsection{Challenges of the water supply project}

Challenges of the water project was assessed through unstructured interview and water analysis. The results of the interview were tabulated in Table 1

Table 1 Challenges of water supply project and participants' reports

\begin{tabular}{|l|l|l|l|l|}
\hline $\mathbf{S} / \mathbf{N}$ & $\begin{array}{l}\text { Criteria for } \\
\text { assessment }\end{array}$ & Challenges & Participant Reports & Remark \\
\hline $\mathbf{1}$ & $\begin{array}{l}\text { Water } \\
\text { quality after } \\
\text { treatment }\end{array}$ & Water has colour & $\begin{array}{l}\text { Water comes out of the faucet } \\
\text { clear, but turns orange-brown } \\
\text { colour after standing for a } \\
\text { period of two days }\end{array}$ & $\begin{array}{l}\text { Presence of dissolved ferrous } \\
\text { iron }\end{array}$ \\
\cline { 3 - 5 } & $\begin{array}{l}\text { Water has metallic } \\
\text { taste }\end{array}$ & $\begin{array}{l}\text { The entire community depend } \\
\text { on sachet water and those who } \\
\text { cannot afford it, boil the public }\end{array}$ & $\begin{array}{l}\text { Presence of dissolved ferrous } \\
\text { iron. Water is not potable and } \\
\text { palatable }\end{array}$ \\
\hline
\end{tabular}




\begin{tabular}{|c|c|c|c|c|}
\hline & & & $\begin{array}{l}\text { water and drink it as they have } \\
\text { no choice. }\end{array}$ & \\
\hline 2. & Technical & $\begin{array}{l}\text { No laboratory in the } \\
\text { treatment plant to } \\
\text { analyze water quality. } \\
\text { No pressure tank and } \\
\text { no additional pump } \\
\text { were installed. No } \\
\text { qualified Engineer } \\
\text { was employed. There } \\
\text { is unavailability of } \\
\text { spare parts. }\end{array}$ & $\begin{array}{l}\text { Empty bottle water was used } \\
\text { by the treatment plant operator } \\
\text { to check water colour by sight. } \\
\text { There is no extra pump that will } \\
\text { serve as a backup in case there } \\
\text { is need for servicing of the } \\
\text { pumps. } \\
\text { One water points has broken } \\
\text { pipe. Five have leaking adapter. } \\
\text { All these serve as an avenue for } \\
\text { water wastage }\end{array}$ & $\begin{array}{l}\text { The treatment plant lacks both } \\
\text { qualified professional and } \\
\text { adequate facilities. There is no } \\
\text { chlorine test kit to test for free } \\
\text { chlorine at users' point } \\
\text { This shows that the project is } \\
\text { not technically reliable. } \\
\text { The broken pipe is a sign of } \\
\text { careless use and/or overuse by } \\
\text { water users. }\end{array}$ \\
\hline 3 & Financial & $\begin{array}{l}\text { The project has no } \\
\text { financial budget } \\
\text { mechanism for its } \\
\text { maintenance }\end{array}$ & & \\
\hline
\end{tabular}

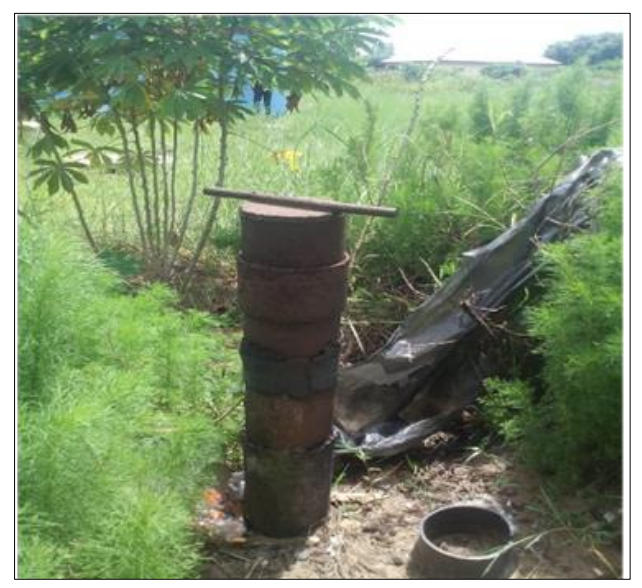

Figure 2a The Deep Well for water abstraction

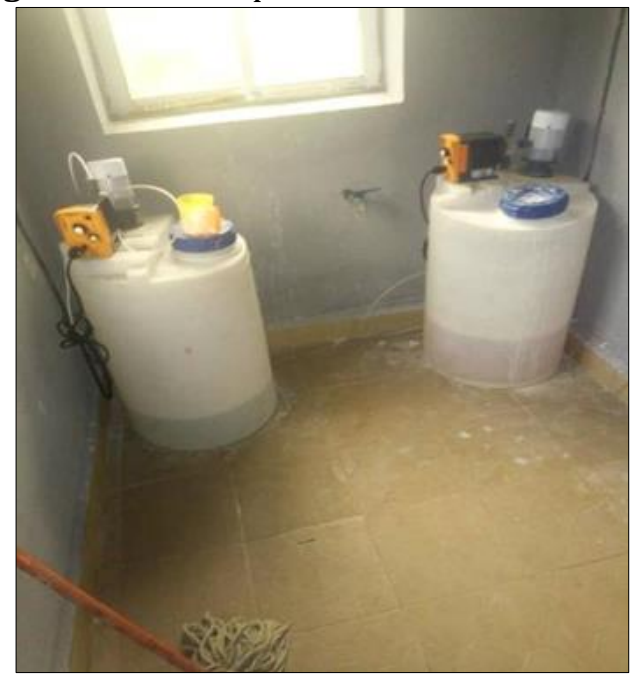

Figure 2c chemical treatment unit

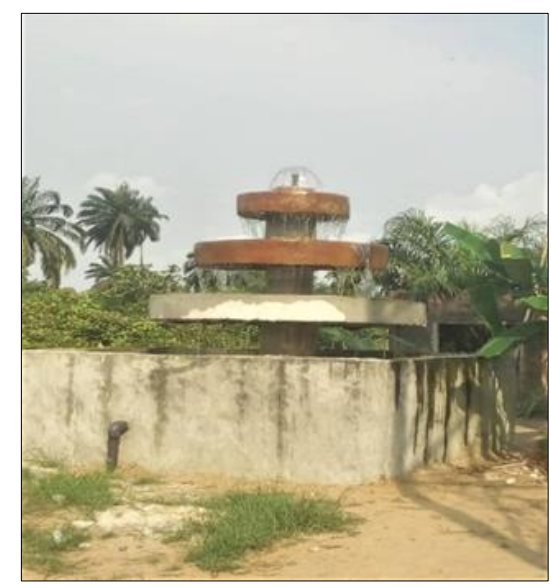

Figure 2b Cone aerator

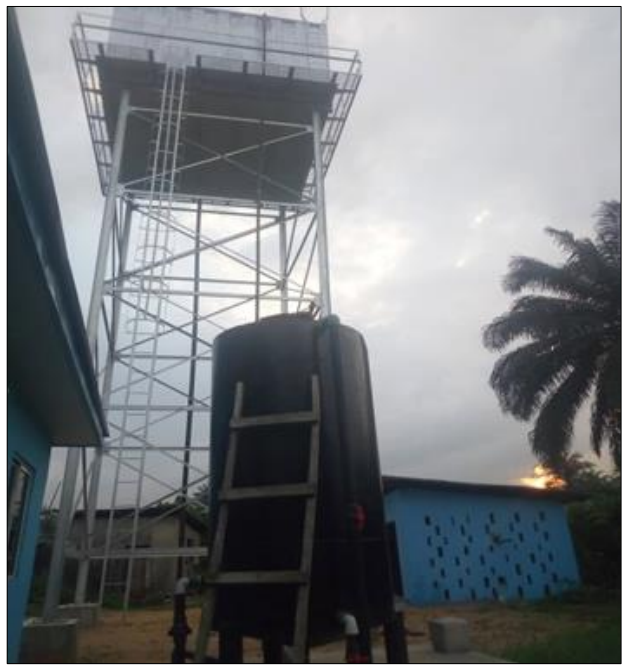

Figure 2d Pressure Filter and overhead tank

Figures $2 \mathrm{a}, 2 \mathrm{~b}, 2 \mathrm{c}$, and $2 \mathrm{~d}$ are different component of the community water supply project. 


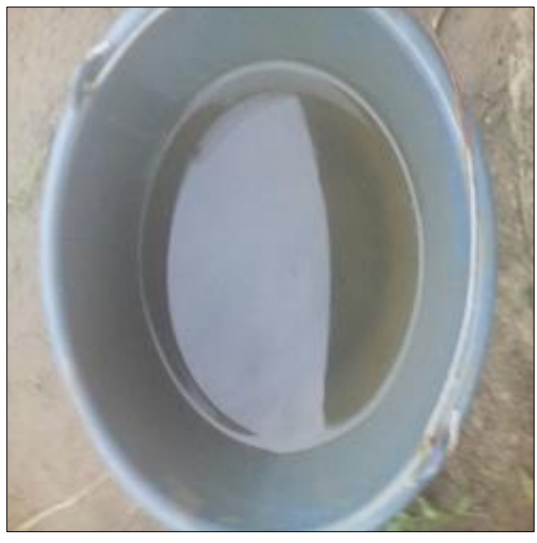

Figure 3a before treatment

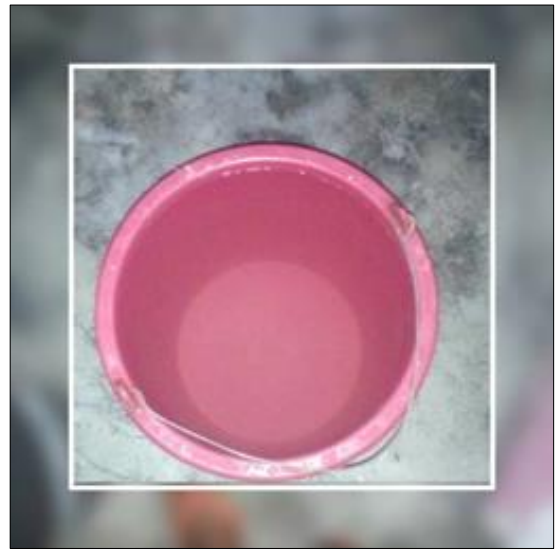

Figure $\mathbf{3 b}$ after treatment

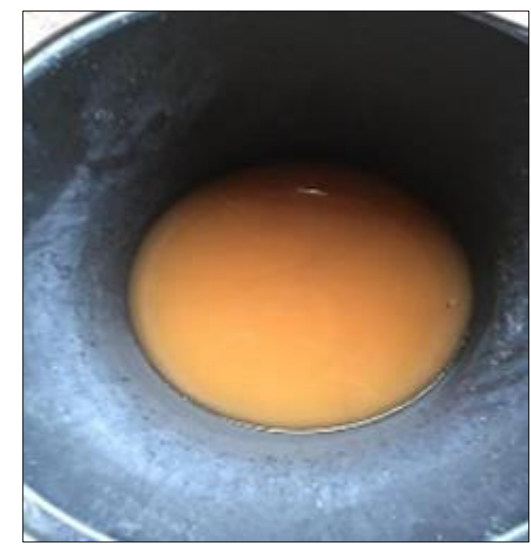

Figure 3c after two days of standing

Table 2 Average value of treated water from users point immediately after treatment

\begin{tabular}{|c|c|c|c|c|}
\hline Parameter & minimum & maximum & Average value & WHO median value \\
\hline Total coliform & 9.18 & 9.25 & 9.2 & 0 per $100 \mathrm{ml}$ \\
\hline $\mathrm{pH}$ & 6.30 & 6.39 & 6.33 & $6.5-8.5$ \\
\hline Total Hardness & 135 & 138 & 137 & $500 \mathrm{mg} \mathrm{CaCO3/1}$ \\
\hline Colour & 9.5 & 10.5 & 10 & 15 \\
\hline Total dissolve solid & 147.30 & 150 & 148.10 & 1000 \\
\hline Alkalinity & 178 & 183 & 180.0 & Not available \\
\hline Iron & 2.20 & 2.25 & 2.221 & 0.3 \\
\hline Iron bacteria & moderate & moderate & moderate & Not available \\
\hline Nitrate & 2.45 & 2.60 & 2.51 & 50 \\
\hline Lead & $<0.001$ & $<0.003$ & $<0.002$ & 0.01 \\
\hline Taste & objectionable & objectionable & objectionable & Not available \\
\hline Turbidity & 11.5 & 13 & 12 & 5 \\
\hline Manganese & 0.99 & 1.0 & 0.994 & 0.1 \\
\hline Free chlorine & 0.25 & 0.35 & 0.3 & Not available \\
\hline Elect.conductivity & 326 & 340 & 333.00 & Not available \\
\hline
\end{tabular}

Note: All values are in $\mathrm{mg} / \mathrm{l}$ except Electrical conductivity in $\mu \mathrm{S} / \mathrm{m}$, total coliform count in MPN per 100ml, Turbidity in NTU, color in True Colour Unit (TCU) [9]

\section{Discussion}

Water sample in Figure 3a showed high levels of turbidity with an oily sheen and so can protect microorganisms from the effects of disinfection, stimulate the growth of bacteria, and exert a significant chlorine demand. Where disinfection is practiced, the turbidity must always be below 5 NTU and ideally below 1 NTU for effective disinfection. The colour of the water in Figure $3 \mathrm{~b}$ is initially clear after treatment but turns orange-brown colour over time in Figure 3C. The colour resulted from the presence of dissolved ferrous iron and the condition is known as the reduced form of iron metals. Anaerobic groundwater may contain ferrous iron at concentrations up to several milligrams per litre without discoloration or turbidity in the water when directly pumped from a well [10]. On exposure to the atmosphere, however, the ferrous iron oxidizes to ferric iron, giving an objectionable reddish-brown colour to the water. These reduced forms of iron and manganese are most common in groundwater with a $\mathrm{pH}$ of less than 7.0. 
Table 2 showed that the result of Ikuru water quality obtained from the user points after treatment. Manganese concentrations was above-recommended level. Taste was objectionable. Water was hard since its range is between $120-$ $180 \mathrm{mg} / \mathrm{l}$. The water sample was turbid at $12 \mathrm{NTU}$, which was above the WHO safe limit. Total coliform and Iron bacteria were present. That could be that the chemical agents used in the treatment (chlorine and HTH) have been neutralized or inactivated by the presence of other organic or inorganic substances present in water. Hence, the depletion of concentration of the chemical agents below the level necessary for the effective bactericidal kill.

Table 1 showed that there is no water lab to analyze the groundwater quality before and after treatment. Public water suppliers are required by law to routinely test their water and treat it to meet water quality standards. The community manages the maintenance of the entire operation of the water supply system. There was no support mechanism to fill the gap when communities cannot raise funds for major repairs. The operators of this treatment plant are two nonprofessionals who are in charge of the whole treatment process. The result of the interviews with community members showed partial dissatisfaction with the project due to its water quality. The frequent breakdown of treatment plant components could be lack of preventive maintenance, or technical know-how. The delay in fixing faulty parts could be attributed to either insufficient funds or a lack of external support.

\section{Conclusion}

Aesthetic parameters are those detectable by the senses, namely turbidity, colour, taste, and odour. They are important in monitoring community water supplies because they may cause the water supply to be rejected and alternative (possibly poorer-quality) sources to be adopted. The quality of the water is aesthetically clear immediately after treatment judging from its appearance, but changes after two days of standing to orange-brown colour. That indicates that the water sample did not receive adequate treatment. Aeration, chemical oxidation followed by filtration were not able to work satisfactorily. The chlorination process was not able to handle iron concentration and iron bacteria successfully.

\section{Recommendation}

Everyone has the right to portable and palatable water and this right is recognized in international legal instruments which provides for sufficient, safe, accessible and affordable water for personal and domestic uses. Therefore, there is needs for drastic treatment of Ikulu community water project at the point source using shock chlorination as a recommended method. Another effective method is the application of aeration, granular or powdered activated carbon and ozonation to improve its performance level. Moreover, supportive intervention is required from governmental institutions to overcome the challenges of this water project for sustainability.

\section{Compliance with ethical standards}

\section{Acknowledgments}

The authors wish to thank Engr. Danju Barthram Ikuru and Miss. Vivian Nzediegwu Onyinyechi for their assistance in data collection, water sampling and analysis report used in this study.

\section{Disclosure of conflict of interest}

The authors declared that there is no conflict of interest regarding this publication.

\section{References}

[1] Adejuwon JO. Rainfall seasonality in the Niger Delta Belt, Nigeria. Journal of Geography and Regional Planning. 2012; 5(2): 51-60. 18 January 2012.

[2] Oteri AU, Atolagbe FP. Saltwater intrusion into coastal aquifers in Nigeria. ICSICA. Mexico. 2003.

[3] Akinwumiju AS, Orimoogunje 00. Predicting the yields of deep wells of the Deltaic Formation, Niger Delta, and Nigeria. Journal of Environmental Toxicology. 2013; 3: 168.

[4] Ujile AA. Groundwater contamination: performance limitations and impacts in Niger Delta-Nigeria. Groundwater contamination. Nova science publishers, inc. 2017.

[5] Ayotamuno MJ, Kogbara RB. Response of Environmental Characteristics to Industrialization: A case study of the Onne Oil and Gas,' Journal of Food, Agriculture and Environment. 2007; 5(1): 288- 289. 
[6] Ujile AA. Modeling groundwater contaminants due to transient sources of pollutants. PhD Dissertation. RSUST, Nigeria. 2003.

[7] Oteri UA. A study of the effects of oil spills on groundwater. In: Proceedings of 1981 International Seminar. The petroleum industry and the Nigerian Environment. 1981; 89.

[8] APHA (American Public Health Associatio. Standard methods for the examination of water and wastewater (20th ed.). Washington DC. 1998.

[9] World Health Organization (WHO). A global overview of national regulations and standards for drinking water quality. Geneva: World Health Organization; 2018. Licence: CC BY-NC-SA 3.0 IGO.

[10] World Health Organization (WHO). Guidelines for drinking-water quality: fourth edition incorporating the first addendum. Geneva: World Health Organization; 2017. Licence: CC BY-NC-SA 3.0 IGO 